\title{
High-resolution analysis of radial growth and wood density in Eucalyptus nitens, grown under different irrigation regimes
}

\author{
Rupert Wimmer $^{\mathrm{r}^{*}}$, Geoffrey M. Downes ${ }^{\mathrm{b}}$ and Robert Evans ${ }^{\mathrm{c}}$ \\ ${ }^{a}$ Universität für Bodenkultur Wien, Institute of Botany, Gregor Mendelstrasse 33, 1180 Vienna, Austria \\ ${ }^{\mathrm{b}}$ CSIRO Forestry and Forest Products, GPO Box 252-12, Hobart, TAS 7001, Australia \\ ${ }^{c}$ CSIRO Forestry and Forest Products, Private Bag 10, Clayton South MDC, VIC 3169, Australia
}

(Received 5 July 2001; accepted 11 February 2002)

\begin{abstract}
Wood density is the most important determinant of wood quality and a critical factor in short rotation forestry. Daily radial growth of six-year-old Eucalyptus nitens trees were monitored on a two hectare plantation in south-eastern Tasmania using point dendrometers, under different irrigation regimes. At the end of the second growing season 12-mm cores were extracted from the trees and processed for high-resolution wood density using SilviScan-2. The dendrometer measurements were utilized to rescale wood density on a time axis. In general, lower density was formed early in the growing season, and higher wood density later. The irrigated-droughted trees showed an obvious relationship between wood density and soil water deficits with the density decreasing in response to water stress releases. The density decrease was accompanied by acceleration in daily increment. With the presented approach the annual level is no longer the basis of analysis. This opens new opportunities for genotype $\times$ environmental interaction studies of trees, which is of particular importance in clonal forestry.
\end{abstract}

wood density / dendrometer / wood quality / irrigation / cambium

Résumé - Analyse haute résolution de la croissance radiale et de la densité du bois d'Eucalyptus nitens, croissant sous divers régimes d'irrigation. La densité du bois est le plus important déterminant de la qualité du bois et un facteur critique pour la sylviculture en courte rotation. La croissance radiale journalière d'Eucalyptus nitens, âgé de 6 ans, a été suivie dans une plantation de 2 hectares dans le Sud-Est de la Tasmanie en utilisant des dendromètres à point, sous différents régimes d'irrigation. À la fin de la seconde saison de végétation, des carottes de $12 \mathrm{~mm}$ ont été prélevées sur les arbres et une mesure haute résolution de la densité du bois a été réalisée à l'aide d'un SilviScan-2. Les mesures à l'aide du dendromètre ont été utilisées pour recaler la densité du bois sur un axe de temps. En général, le bois ayant la densité la plus faible a été formé tôt dans la saison de végétation, et le bois de haute densité plus tardivement. Les arbres irrigués ou soumis à la sécheresse montraient une relation évidente entre la densité du bois et le déficit hydrique du sol avec une densité diminuant en réponse à une réduction du stress hydrique. La diminution de densité a été accompagnée par une accélération de l'accroissement journalier. Selon l'approche présentée, le niveau annuel ne sera plus la base de l'analyse. Ceci ouvre de nouvelles opportunités pour des études de l'interaction génotype $\times$ environnement sur des arbres, ce qui est d'une importance primordiale en foresterie clonale.

densité du bois / dendromètre / qualité du bois / irrigation / cambium

\section{INTRODUCTION}

Wood is a non-uniform, heterogeneous material throughout the tree stem. Wood structure, chemical components and mechanical properties vary from pith to bark, from the tree base to the top, from stem to branch and root. At higher magnification wood varies systematically within one growth ring and at the cellular level, the chemistry, the microfibril angle and mechanical properties change significantly from one cell wall layer to the other [12]. As concluded by Larson [21], "more variability in wood characteristics exists within a single tree than among trees growing on the same site or between trees growing on different sites". Causes of variation may be generally categorized as being the result of specific environmental factors or internally controlled genetic factors [39]. These factors are always subjected to interactions between the genetic potential of a tree to produce a certain kind of wood and the influence exerted by the environment. In other

* Correspondence and reprints

Tel.: +43 664 3165155; fax: +43 147654 3180; e-mail: wimmer@mail.boku.ac.at 
words, the genetic component of a species sets its potential for growth, and environmental constraints limit the expression of that potential.

Wood density is the most important determinant of wood quality. It is the strongest predictor for paper properties $[2,8$, $23]$ and mechanical strength of sawn timber. Wood density of trees is a critical factor in short rotation forestry, where the proportions of juvenile wood are relatively high. However, wood density can be changed by silvicultural practices [33] and genetic manipulation [31]. Silvicultural practices and genetic improvement may result in rapid tree growth but concerns exist about possible effects on wood quality. Zobel and van Buijtenen [40] state that wood from fast-grown plantation is not necessarily "bad wood" but it is certainly different. An important aspect in wood quality is the frequently discussed relationships between wood density and ring width. Some studies concluded that in conifers there is little relationship, while others found either negative or positive relationships between ring width and wood density $[3,9,28,37]$.

Seasonal variation in cambial activity gives rise to large differences in wood properties but this question was rarely considered because of methodological difficulties. To obtain a clearer picture of cambial conditions at times that can be related to wood properties produced, new ways to look at these processes are required. In recent years, new emerging technologies have allowed rapid and efficient characterisation of wood $[7,10,11]$. These new evaluation techniques are especially useful for measuring the high variation of wood properties, including wood density.

The cambium encompassing the woody stem produces a range of wood properties at any given point in time. Therefore, spatial measurements of targeted properties across annual rings need to be converted to a time scale, from a distance scale. But attempts to generate stamps in wood at times when it was formed in the cambium have lacked appropriate resolution. Repeated cambium wounding $[20,24]$ has been used to set time markers, as the wounds generate callus tissue, which remains as an artificial and datable scar in the wood. Schmitt et al. [32] used repeated wounding throughout the growing season to put time stamps in the differentiating tissues. However, all these attempts operate at a very limited time resolution.

Band dendrometers have been used successfully to obtain high-resolution growth data. These bands are often made of stainless steel or invar and mounted around the tree stem to monitor changes in circumference. The band movements are measured manually through gauges, calliper or registered electromechanically using potentiometers [14]. These dendrobands have been prominent in different studies, such as investigating tree water status [22], drought effects [14] or ozone and climate effects on tree growth [25]. An alternative to bands are point dendrometers to monitor the radial movements of tree stems $[5,16,41]$. Point dendrometers are usually mounted on stainless steel rods that are inserted into the wood. They provide a linear measure of the stem movements, which is more directly related to processes going on in the cambium, at a particular point.

This paper reports on temporally resolved variability of wood density in Eucalyptus nitens, over the period of two growing seasons. Dendrometers were used to monitor radial stem movements and cores were taken after the observation period to measure wood density at a linear resolution of $50 \mu \mathrm{m}$. Wood density was then mapped on a daily time axis. The trees grew under different irrigation regimes and daily growth processes were compared with concurrently formed wood density.

\section{MATERIALS AND METHODS}

\subsection{Sites}

In a two-hectare plantation located in Lewisham, southeastern Tasmania ( $\left.42^{\circ} 49^{\prime} \mathrm{S}, 147^{\circ} 36^{\prime} \mathrm{E}\right)$ six-year-old E. nitens trees were selected for this research [27]. Stocking rate was 1428 stems ha ${ }^{-1}$ and tree growth (height, stem diameter) as well as water use have been monitored intensively since establishment in August 1990. The soil consists of a shallow red-brown loam A horizon and light brown, medium clay B horizon, occasionally overlaying light yellow-brown gritty loam from decomposing rocks. Parent material is basalt with sandstone floaters intruding in the southwestern corner of the plantation. Mean soil depth to bedrock was $0.6 \mathrm{~m}$. The long term meteorological averages at Hobart airport, $9 \mathrm{~km}$ west of the site, were, mean January maximum / minimum temperature 22.3 / $11.8^{\circ} \mathrm{C}$, mean July maximum / minimum temperature $12.2 / 4.0^{\circ} \mathrm{C}$, and mean annual rainfall $512 \pm 115 \mathrm{~m}$. Annual rainfall was below that normally suited to plantation establishment. Six weeks after planting, phosphorus was applied as triple superphosphate at $120 \mathrm{~kg} \mathrm{ha}^{-1}$ elemental P. Nitrogen was applied as urea at $100 \mathrm{~kg} \mathrm{ha}^{-1}$ elemental $\mathrm{N}$ in three applications (40\% in August, 30\% in both December and March) in 1990/91 and 1991/92 and at $60 \mathrm{~kg} \mathrm{ha}^{-1} \mathrm{~N}$ each August from 1992 to 1996.

\subsection{Experimental design}

The plantation was divided into three equally sized plots and on each plot two trees were randomly selected. The first plot was irrigated (treatment A) to avoid water stress, and the other two plots (treatments B and C) were managed under cycles of drought. Irrigation was applied through micro-sprinklers and soil water deficits of the irrigated plot (treatment A) were not allowed to exceed around $40 \mathrm{~m}$ [15], except on two occasions during winter to encourage root development. Soil water deficit was defined as the amount of water required returning the soil to field capacity. Irrigation was applied frequently in small amounts $(10 \mathrm{~m})$ to avoid large changes in water content between fortnightly monitored events [35]. Treatment B was subjected to a series of irrigation and drying cycles. This created high fluctuations in soil water deficits during the two years of observation. Treatment $\mathrm{C}$ was droughted in a way that a complete drying of the soil profile was allowed. The drought stress has been interrupted only by rainfall or by small application of irrigation to prevent death of trees. 


\subsection{Monitoring tree growth}

Point dendrometers (Agricultural Electronics Corporation, Tucson, Arizona) were installed in March 1995 on all six E. nitens at about $25 \%$ of tree height, which corresponded to approximately $3 \mathrm{~m}$ actual height. Dendrometers were mounted on $4 \mathrm{~mm}$ stainless steel threaded rods inserted $40 \mathrm{~mm}$ into the wood. Each dendrometer was individually calibrated and a $4 \mu \mathrm{m}$ change in radius corresponded to approximately $1 \mathrm{mV}$. Radial growth on the northern side of the tree was monitored every fifteen minutes during the growing season from August 1996 to July 1998. August represented the start of spring growth in these trees, and radial growth accelerated around mid August. From these measurements hourly and daily increments of stem radius were determined.

\subsection{Wood data}

In September 1998, 12-mm cores were extracted using a powered borer from the trees approximately $300 \mathrm{~mm}$ below the sensing head of the dendrometer. Cores were treated as described in Downes et al. [7] by replacing water with $100 \%$ ethanol followed by air-drying. This minimized shrinkage, distortion, or possible collapse of wood fibres and vessels. Radial profiles of conditioned wood density were determined using SilviScan-2 [11] at a $50 \mu \mathrm{m}$ step size.

\subsection{Relating stem growth to wood properties}

Specific software procedures were written in IDL (RSI Inc.) to handle hourly dendrometer data, extracting rates and duration of stem shrinkage and expansion in each 24 hour period, as shown previously in Downes et al. [5, 6]. The trees commonly experienced a shrinkage phase during the early part of the day followed by an expansion phase during the afternoon and evening. Figure 1 shows typical diurnal cycles in summer over 3 days. From this pattern three distinct phases were defined within a single diurnal cycle. The "shrinkage" phase was defined as that period during which the tree decreased in radius, usually from an early morning maximum. The "recovery" phase was defined as that portion of the cycle during which the radius increased until it reached the position observed previously. Finally, the "increment" phase was defined as the period during which the stem radius continued to increase until the shrinkage phase commenced in the next diurnal phase [5]. By processing the measured data the shrinkage, recovery and increment were resolved into a rate $\left(\mu \mathrm{m} \mathrm{h}^{-1}\right)$ and duration $(\mathrm{h})$.

Additional software procedures were developed (Downes unpublished) to allow the daily growth to be associated with radial

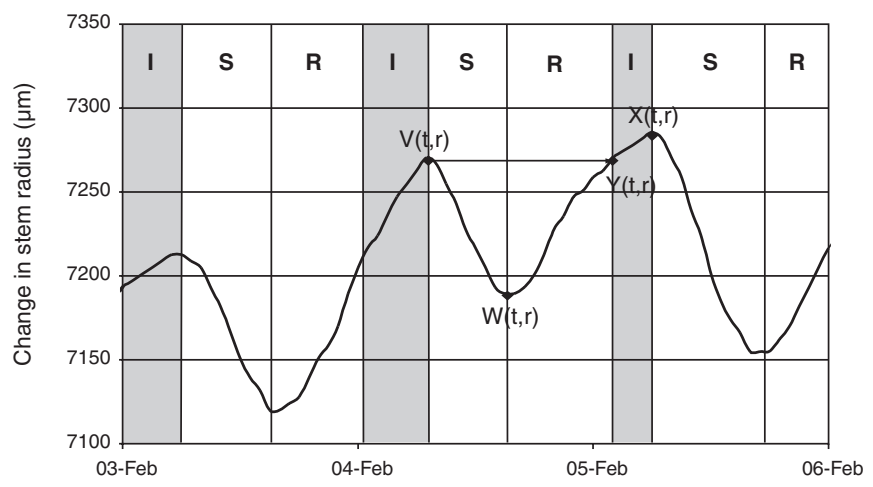

Figure 1. Diurnal cycles over three days with the phases stem shrinkage (S), stem recovery $(\mathrm{R})$ and increment (I). wood increments. The basic problem to solve is the fact that measured wood properties are on a distance scale, the growth data on a time scale. If growth rates are assumed to be linear and constant over the year, it is obvious that a direct correspondence exists between the spatial and temporal scale of measurements. However, as this is normally not the case another approach is required to successfully relate these two different scales. One approach is to use the pattern of growth over time as a template for mapping wood properties onto a time axis. As dendrometers also measure distance over time, there is a common axis with the measured wood properties. The axis of the dendrometer data is therefore rotated in a way that the radial distances of both measures are plotted on the abscissa. Figure 2 gives an example of the association between wood density and dendrometer data.

Similar IDL (RSI Inc.) procedures were also written for mapping growth and weather data from a daily to a distance basis. As an approximation, it was assumed that the production of phloem was more or less constant throughout the year. The daily dendrometer data were rescaled so that the total ring width was the same for the wood and dendrometer data.

The dendrometer data were smoothed using a 7-day moving average filter and shrinkage events removed. The spatially measured wood property data was mapped onto a daily time step, using the time and distance-based data arrays. A critical step in the mapping process was the identification of growth ring boundaries. The sufficiently defined annual rings of $E$. nitens allowed the start and end of each year's growth to be identified.

\section{RESULTS}

The average annual ring width over two years was highest in the irrigated plot (treatment A, $10.1 \mathrm{~mm}$ ), medium at the irrigated-droughted plot (treatment $\mathrm{B}, 6.9 \mathrm{~mm}$ ) and smallest at the droughted plot (treatment C, $4.4 \mathrm{~mm}$ ). Stem diameter changes were recorded over two growth periods commencing 1st August 1996, and wood density was scanned for the wood formed during this period. Figure $3 a-c$ presents timemapped wood density for each treatment plotted along with soil-water deficits. Lower wood density was formed during the first months of each growing season (earlywood) with an increase later.

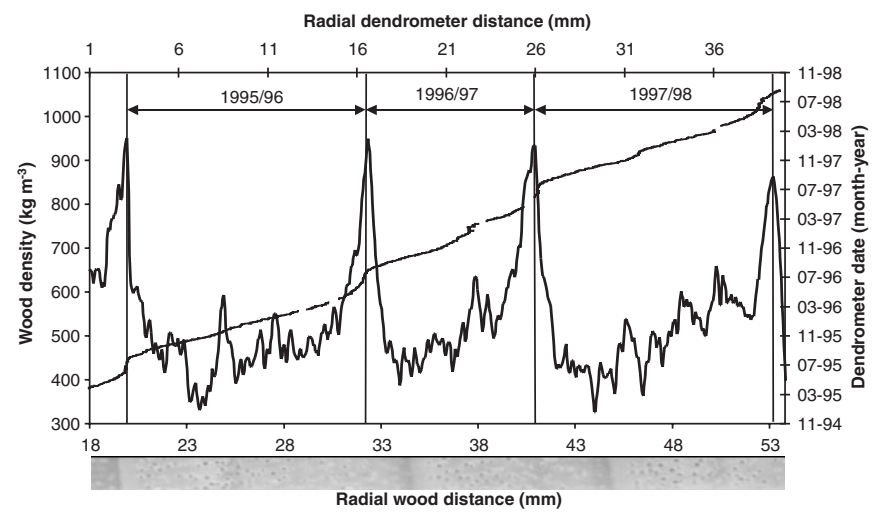

Figure 2. Distanced based wood density measurement mapped with hourly measured dendrometer data of an irrigated E. nitens, over three growing seasons. 

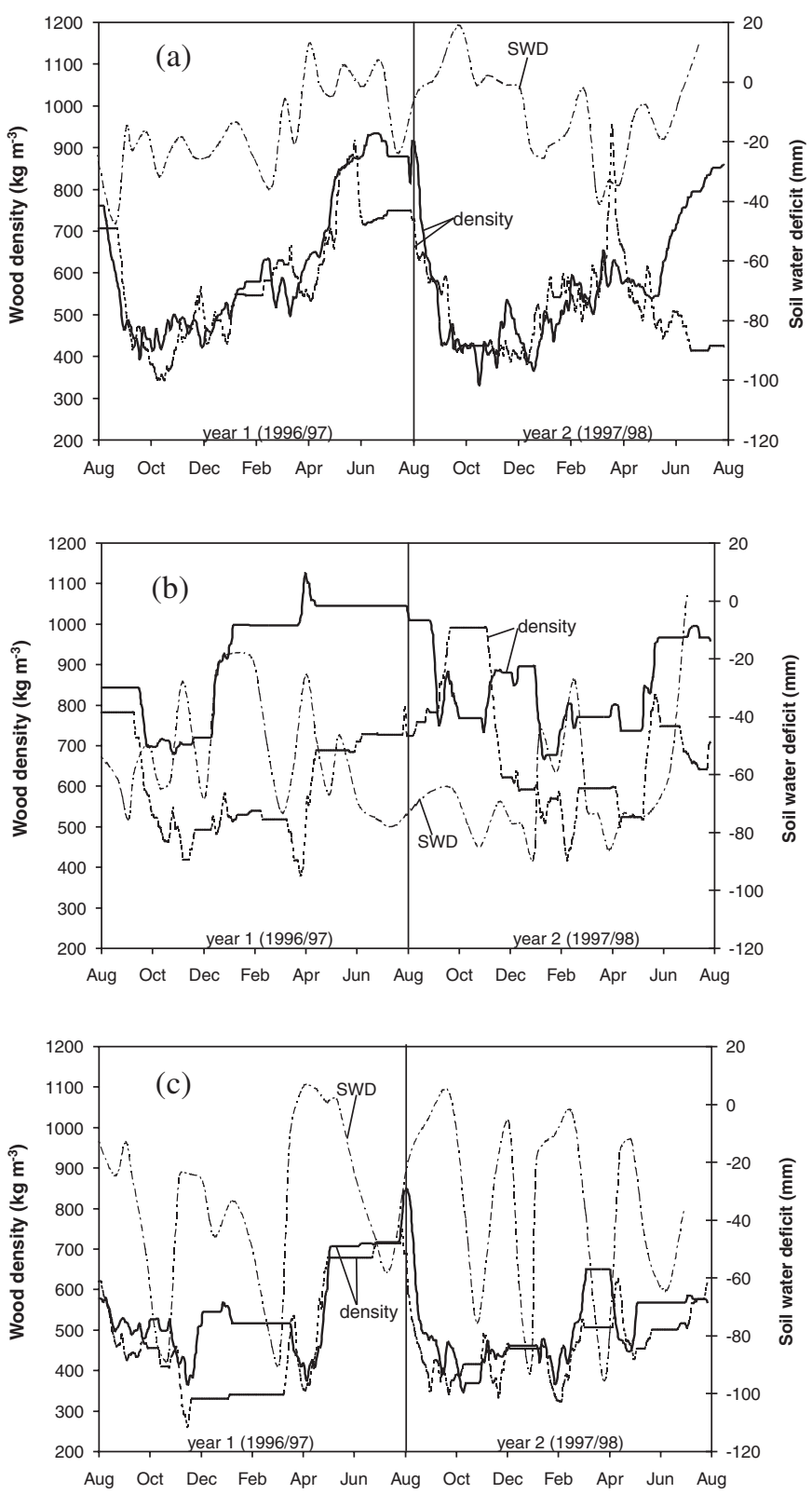

Figure 3. Time-trends for wood density of two E. nitens trees over two years compared with soil water deficits (SWD), (a) irrigated, (b) irrigated-droughted, (c) droughted.

The irrigated trees (treatment A, figure 3a) showed a relatively smooth seasonal pattern without visible association to soil water deficits. The density range over the two years was about $500 \mathrm{~kg} \mathrm{~m}^{-3}$. Maximum density of around $900 \mathrm{~kg} \mathrm{~m}^{-3}$ was reached at the end of the growing season. The wood density ran synchronous for both trees with the exception of a peak that occurred around March 20 of the second year. This peak was accompanied with higher soil water deficits.

The irrigated-droughted trees (treatment $\mathrm{B}$, figure $3 b$ ) showed a different picture. The wood density of these trees ranged between $270 \mathrm{~kg} \mathrm{~m}^{-3}$ in mid November 1996 to
$850 \mathrm{~kg} \mathrm{~m}^{-3}$ at the end of the second season. The wood density trends of the irrigated-droughted trees were associated with the strong cycles of soil-water status measured each fortnight. At high levels of soil water deficit (under $-40 \mathrm{~mm}$ ) growth of the trees stopped, seen as horizontal density lines in the graph. After recharge of the soil through irrigation tree growth resumed and wood density dropped for a certain period. This can be seen in mid November 1996, begin April 1997 and also around May 1998.

The period between September 25 and December 9, 1996 of the irrigated-droughted trees (treatment B) was extracted for a detailed analysis of wood density and daily increments (figure 4). This 11-weeks period was picked because it included a strong drought cycle. High daily increment rates were recorded on the 1st, 13th and 24th of October and on the 5 th of November (marked in figure 4 as four vertical lines). Wood density changed simultaneously with these increment peaks. On October 1 st the daily increment reached $55 \mu \mathrm{m} /$ day and wood density seemed to respond with an increase. The peak around October 13 had $35 \mu \mathrm{m}$ as daily increment, wood density of both trees dropped a few days later. On October 25 the growth peak of tree 1 ( $48 \mu \mathrm{m} /$ day $)$ coincided with a density peak measured in the wood of the same tree. Between October 27 and November 5 a major increase in daily increment occurred, reaching a maximum rate of $110 \mu \mathrm{m} / \mathrm{day}$. At that time the previously high soil water deficit was fully released. Wood density of both trees dropped while daily increments accelerated reaching a minimum density on November 15 . Later, tree 1 continued to grow with increasing density while tree 2 stopped growing for almost six weeks.

The droughted trees (treatment $\mathrm{C}$, figure $3 c$ ) showed a high wood density range between $400 \mathrm{~kg} \mathrm{~m}^{-3}$ and $1150 \mathrm{~kg} \mathrm{~m}^{-3}$. Soil water deficits were mostly high without obvious association to wood density. Growth of these trees was more retarded than in the other treatments, indicating reduced cambium activity.

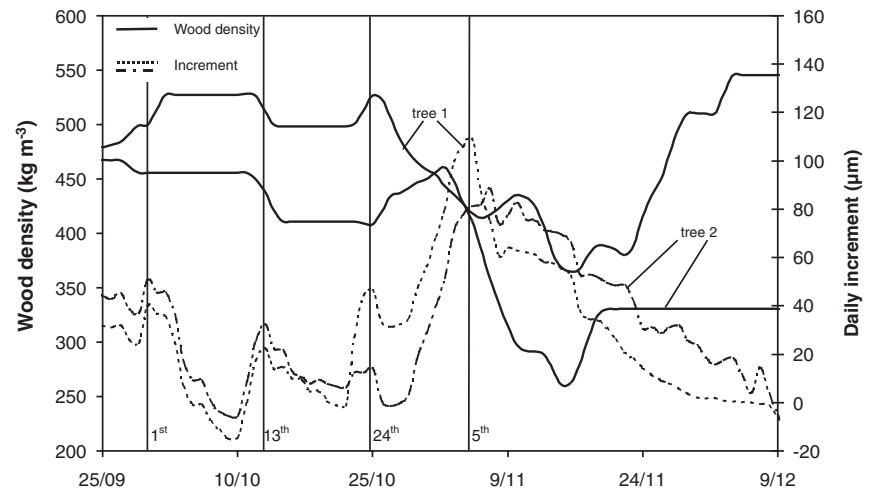

Figure 4. Wood density (solid lines) and daily increment (dashed lines) of the two irrigated-droughted trees; the extracted period between 25.09.1996 and 9.12.1996 is shown. 


\section{DISCUSSION}

In this research radially measured stem-movements have been successfully combined with high-resolution wood density. Distance based density measurements were transformed and mapped onto a time axis that allowed synchronous comparisons between trees across treatments. With this approach it was possible to monitor wood formation at a particular spot on a tree over two years. Other methods using periodic wounding or repeated cambium sampling have faced the problem of wound effects, which were avoided by moving the locations for sampling either downwards [1] or around the circumference [34].

The cambial region undergoes severe water stress almost daily during the growing season because of high tensile forces that develop in the adjacent mature xylem [36]. Under these conditions, the size of the meristematic cells and the duration of the cell division cycle in these cells determine the rate of cell production. Cambial derivatives differentiating into xylem vessels and fibre tracheids of eucalypts subsequently undergo a sequence of changes including cell enlargement with continued primary wall formation, secondary deposition wall deposition and lignification. The final phase of cell development is the autolysis of the cell contents to reach full maturity [30].

Herzog et al. [13] compared diurnal variation in stem diameter with sapflow and defined five phases of the diurnal curve in relation to water movement into and out of the cambial region. These phases were generally consistent with the patterns observed in this study and the three extracted phases are clear, mathematically definable portions of the diurnal cycle. "Increment" was the phase when a net radial increase occurred, which is not necessarily identical with "growth" per se as the cell division and expansion phases in the cambium were not directly monitored. However, it is assumed that most activity occurred during the increment phase, when water availability to the cambium is at a maximum [1, 26]. For example, Richardson [29] reported that night-time temperature had a stronger relationship with fibre length than average daily temperature. Intensive growth of primary cell walls was also observed during night hours by Antonova [1]. Further research should try to link daily dynamics of cell division and expansion with radial stem movements and water status of trees.

The dendrometer measurements may be inaccurate for two reasons, both of them related to the cambium. The positional movement recorded by the dendrometers could be influenced by variations in cambium width during a growing season. For mid growing season the number of cambial zone cells in Eucalyptus globulus undergoing differentiation can be as high as 100 cells for the phase of secondary wall development, measured at breast height [30]. Because the determined increments from the stem movements are the incremental changes relative to the previous days, no significant effects were expected coming from low-frequency thickness changes of the cambium. Similarly, frequent changes in phloem thickness in the order of days are unlikely and therefore also negligible. In addition, the rate of tissue production on the phloem side of the cambium is far less than on the xylem side of most species [38].

The measured trees showed the usual trend of lower density formed during the early growing season and higher density formed during the later part [4]. Particularly the irrigated-droughted trees, with expressed cycles of soil-water deficits on that site, have shown an association between wood density and soil water deficits with wood density appearing to drop in response to releases from water stress. This density decrease was accompanied with increases in daily radial increments, however, in some cases density and dendrometer data appeared to be out of phase (e.g. Oct. 1, figure 4), which may be explained by the time taken for the effect of water stress to be expressed through the cambial region before it is observed in the mature wood. It is generally agreed that the development of water stress in trees influences almost every aspect of wood formation, including the duration of cambial activity [36]. Water stress can reduce growth directly through a reduction of the cell turgor and interfering with metabolism and cell enlargement. But growth reduction might also act indirectly by decreasing the synthesis of auxin and carbohydrates, combined with a slower translocation to the cambium [18]. However, in the case of short-term changes in water-stress, growth reduction is probably a direct effect because the rate of polar auxin transport is not rapid enough to account for the quick reactivation of the cambium.

Studies on the effect of water stress on specific gravity or percentage of latewood have been shown by Zahner [36] but only at the annual ring level. Numerous studies are dealing with changes in the ratios of earlywood and latewood or changes of growth period length in response to extreme drought [19]. It has been reported by numerous investigators that irrigation in summer and early fall results in higher wood specific gravity because of greater latewood production [40]. Other studies, some of them also on hardwoods, investigated wood production in years with climate extremes and have deduced some moisture effects on wood quality [17].

\section{CONCLUSIONS}

The effect of moisture on wood quality has been a prominent topic in the literature during the past decades. Moisture is recognized as being a major factor in controlling wood properties. With the presented approach the annual level was not the basis of analysis. With point dendrometers attached to trees combined with analysis of cores taken after a period of recording, wood properties of trees from different treatments were comparable because they can be converted to a common time axis. This opens new opportunities for genotype $\times$ environmental interaction studies of trees, particularly important in clonal forestry [39]. The analysis may include other types of distance based wood characteristics, such as microfibril 
angles, cell sizes, chemical parameters, with the benefit of recognizing the complex relationships among wood characteristics at a highly resolved time scale, which could help a great deal to improve our understanding of wood formation. So far, the presented approach has been shown with plantation grown eucalypts only. Therefore, future research should explore other hardwoods as well as softwood species, grown under different environments and forest management regimes.

Acknowledgments: This research was funded by the Cooperative Research Centre for Hardwood Fibre and Paper Science, Fletcher Challenge Paper (now Norske Skog) and North Forest Products, Triabunna. The senior author was supported through the APART program of the Austrian Academy of Science. Thanks to Dale Worledge, CSIRO Forestry and Forest Products for site maintenance and providing the soil water data.

\section{REFERENCES}

[1] Antonova G.F., Cherkashin V.P., Stasova V.V., Varaksina T.N., Daily dynamics in xylem cell radial growth of Scots pine (Pinus sylvestris L.), Trees 10 (1995) 24-30.

[2] Artuz-Siegel E.A., Wangaard F.F., Tamalong F.N., Relationships between fiber characteristics and pulp-sheet properties in Philippine hardwoods, Tappi 51 (1968) 261-267.

[3] Blouin D., Beaulieu J., Daoust G., Poliquin J., Wood quality of Norway spruce grown in plantations in Quebec, Wood Fiber Sci. 26 (1994) 342-353.

[4] Cown D.J., Parker M.L., Comparison of annual ring density profiles in hardwoods and softwoods by X-ray densitometry, Can. J. For. Res. 8 (1978) $442-449$.

[5] Downes G., Beadle Ch., Worledge D., Daily stem growth patterns in irrigated Eucalyptus globulus and E. nitens in relation to climate, Trees 14 (1999) 102-111.

[6] Downes G.M., Evans R., Schimleck L.R., Fritts H.C., The commercial cambium: understanding the origin of wood property variation, in: Savidge R.A., Barnett J.R., Napier R. (Eds.), Cell and Molecular Biology of Wood Formation, BIOS Sci., Oxford, 2000, pp. 325-336.

[7] Downes G.M., Hudson I.L., Raymond C.A., Dean G.H., Michell A.J., Schimleck L.R., Evans R., Muneri A., Sampling eucalypt plantations for wood and fibre properties, CSIRO Publishing, Melbourne, Australia, 1997.

[8] DuPlooy A.B.J., The relationship between wood and pulp properties of E. grandis (Hill ex-Maiden) grown in South Africa, Appita 33 (1980) 257-264.

[9] Dutilleul P., Herman M., Avella-Shaw T., Growth rate effects on correlations among ring width, wood density, and mean tracheid length in Norway spruce (Picea abies), Can. J. For. Res. 28 (1998) 56-68.

[10] Evans R., Rapid measurement of the transverse dimensions of tracheids in radial wood sections from Pinus radiata, Holzforschung 48 (1994) 168-172.

[11] Evans R., Downes G.M., Menz D., Stringer S., Rapid measurement of variation in tracheid transverse dimensions in a radiata pine, Appita J. 48 (1995) 134-138.

[12] Gartner B.L., Patterns of xylem variation within a tree and their hydraulic and mechanical consequences, in: Gartner B.L. (Ed.), Plant stems: physiology and functional morphology, Academic Press, San Diego, 1995.

[13] Herzog K.M., Häsler R., Thum R., Diurnal changes in the radius of a subalpine Norway spruce stem: their relation to the sap flow and their use to estimate transpiration, Trees 10 (1995) 94-101.

[14] Hinckley T.M., Bruckerhoff D.N., The effect of drought on water relations and stem shrinkage of Quercus alba, Can. J. Bot. 53 (1975) 62-72.

[15] Honeysett J.L., White D.A., Worledge D., Beadle C.L., Growth and water use of Eucalyptus globulus and E. nitens in irrigated and rainfed plantations, Aust. For. 59 (1996) 64-73.
[16] Impens I.I., Schalck J.M., A very sensitive electric dendrograph for recording radial changes of a tree, Ecology 46 (1965) 183-184.

[17] Knigge W., Schulz H., Einfluß der Jahreswitterung 1959 auf Zellartverteilung, Faserlänge und Gefäßweite verschiedener Holzarten, Holz RohWerkst. 19 (1961) 293-303.

[18] Kramer P.J., The role of water in wood formation, in: Zimmermann M.H. (Ed.), The formation of wood in forest trees, Academic Press, New York, London, 1964, pp. 519-532.

[19] Kramer P.J., Kozlowski T.T., Physiology of woody plants, Acad. Press, New York, 1979.

[20] Kuroda K., Shimaji K., The pinning method for marking xylem growth in hardwood species, For. Sci. 30 (1984) 548-554.

[21] Larson P.R., Wood formation and its concept of wood quality, Yale University, School of Forestry, Bulletin No. 74, 1969.

[22] Lassoie J.P., Diurnal dimensional fluctuations in a Douglas-fir stem in response to tree water status, For. Sci. 19 (1973) 251-255.

[23] Malan F.S., Male J.R., Venter J.S.M., Relationship between the properties of eucalypt wood and some chemical, pulp and paper properties, Paper South Africa (2) (1994) 6-16.

[24] Mariaux A., La périodicité de formation des cernes dans le bois de Limba, Rev. Bois Forêts Trop. 128 (1969) 39-54.

[25] McLaughlin S.B., Downing D.J., Interactive effects of ambient ozone and climate measured on growth of mature forest trees, Nature 374 (1995) 252-254.

[26] Nonami H., Boyer J.S., Primary events regulating stem growth at low water potentials, Plant Physiol. 93 (1990) 1601-1609.

[27] Pederick L.A., Natural variation in shining gum (Eucalyptus nitens), Aust. For. Res. 9 (1979) 41-63.

[28] Petrik A.W., Comparison of anatomical and pulping properties of some fast and slow growing trees, For. Prod. J. 18 (1968) 62.

[29] Richardson S.D., The external environment and tracheid size in conifers, in: Zimmerman M.H. (Ed.), The Formation of Wood in Forest Trees, Academic Press, New York, 1964, pp. 367-388

[30] Ridoutt B.G., Sands R., Quantification of the processes of secondary xylem fibre development in Eucalyptus globulus at two height levels, IAWA J. 15 (1994) 417-424.

[31] Rozenberg P., Cahalan C., Spruce and wood quality: genetic aspects (A review), Silvae Genet. 46 (1997) 270-279.

[32] Schmitt U., Möller R., Eckstein D., Seasonal wood formation dynamics of beech (Fagus sylvatica L.) and black locust (Robinia pseudoacacia L.) as determined by the pinning-technique, J. Appl. Bot. 74 (2000) 10-16.

[33] Williams R.F., Hamilton J.R., The effect of fertilization on four wood properties of slash pine, J. For. 59 (1961) 662-665.

[34] Wodzicki T.J., Mechanism of xylem differentiation in Pinus sylvestris L., J. Exp. Bot. 22 (1971) 670 - 687.

[35] Worledge D., Honeysett J.L., White D.A., Beadle C.L., Hetherington S.J., Scheduling irrigation in plantation of Eucalyptus globulus and E. nitens: a practical guide, Tasforest 10 (1998) 91-101.

[36] Zahner R., Water deficits and growth of trees, in: Kozlowski T.T. (Ed.), Water deficits and plant growth, Academic Press, New York \& London, 1968, pp. 191-254.

[37] Zhang S.Y., Morgenstern E.K., Genetic variation and inheritance of wood density in black spruce (Picea mariana) and its relationship with growth: implications for tree breeding, Wood Sci. Technol. 30 (1995) 63-75.

[38] Zimmermann M.H., Wood formation of wood in forest trees, Academic Press, New York, 1964.

[39] Zobel B.J., Jett J.B., Genetics of wood production, Springer Series in Wood Science, Berlin, Heidelberg, New York, 1995.

[40] Zobel B.J., van Buijtenen J.P., Wood variation - its causes and control, Springer Series in Wood Science, Berlin, Heidelberg, 1989.

[41] Zweifel R., Häsler R., Frost-induced reversible shrinkage of bark of mature subalpine conifers, Agr. For. Met. 102 (2000) 213-222. 